\title{
SAP3PR: A Fortran Program for Calculating Equivalent Nodal Loads Resulting from Pressure on the Faces of 8- to 20-Node Isoparametric Elements
}

D. N. Fanning 


\section{DISCLAIMER}

This report was prepared as an account of work sponsored by an agency of the United States Government. Neither the United States Government nor any agency Thereof, nor any of their employees, makes any warranty, express or implied, or assumes any legal liability or responsibility for the accuracy, completeness, or usefulness of any information, apparatus, product, or process disclosed, or represents that its use would not infringe privately owned rights. Reference herein to any specific commercial product, process, or service by trade name, trademark, manufacturer, or otherwise does not necessarily constitute or imply its endorsement, recommendation, or favoring by the United States Government or any agency thereof. The views and opinions of authors expressed herein do not necessarily state or reflect those of the United States Government or any agency thereof. 


\section{DISCLAIMER}

Portions of this document may be illegible in electronic image products. Images are produced from the best available original document. 


\section{Printed in the United States of America. Available from National Technical Information Service \\ U.S. Department of Commerce \\ 5285 Port Royal Road, Springfield, Virginia 22161 \\ Price: Printed Copy $\$ 4.50$; Microfiche $\$ 3.00$}

This report was prepared as an account of work sponsored by an agency of the United States Government. Neither the United States Government nor any agency thereof, nor any of their employees, contractors, subcontractors, or their employees, makes any warranty, express or implied, nor assumes any legal liability or responsibility for any third party's use or the results of such use of any information, apparatus, product or process disclosed in this report, nor represents that its use by such third party would not infringe privately owned rights. 
ORNL/TM-6091

Dist. Category UC-77

Contract No. W-7405-eng-26

Engineering Technology Division

HTGR BASE TECHNOLOGY PROGRAM

Prestressed Concrete Nuclear Pressure

Vesse1 Development (189a 01331)

SAP3PR: A FORTRAN PROGRAM FOR CALCULATING EQUIVALENT NODAL LOADS RESULTING FROM PRESSURE ON THE FACES OF 8- TO 20-NODE ISOPARAMETRIC ELEMENTS

D. N. Fanning

Date Published - April, 1978

Prepared by the

OAK RIDGE NATIONAL LABORATORY

Oak Ridge, Tennessee 37830

operated by

UNION CARBIDE CORPORATION

for the

DEPARTMENT OF ENERGY 


\section{THIS PAGE}

WAS INTENTIONALLY

LEFT BLANK 
CONTENTS

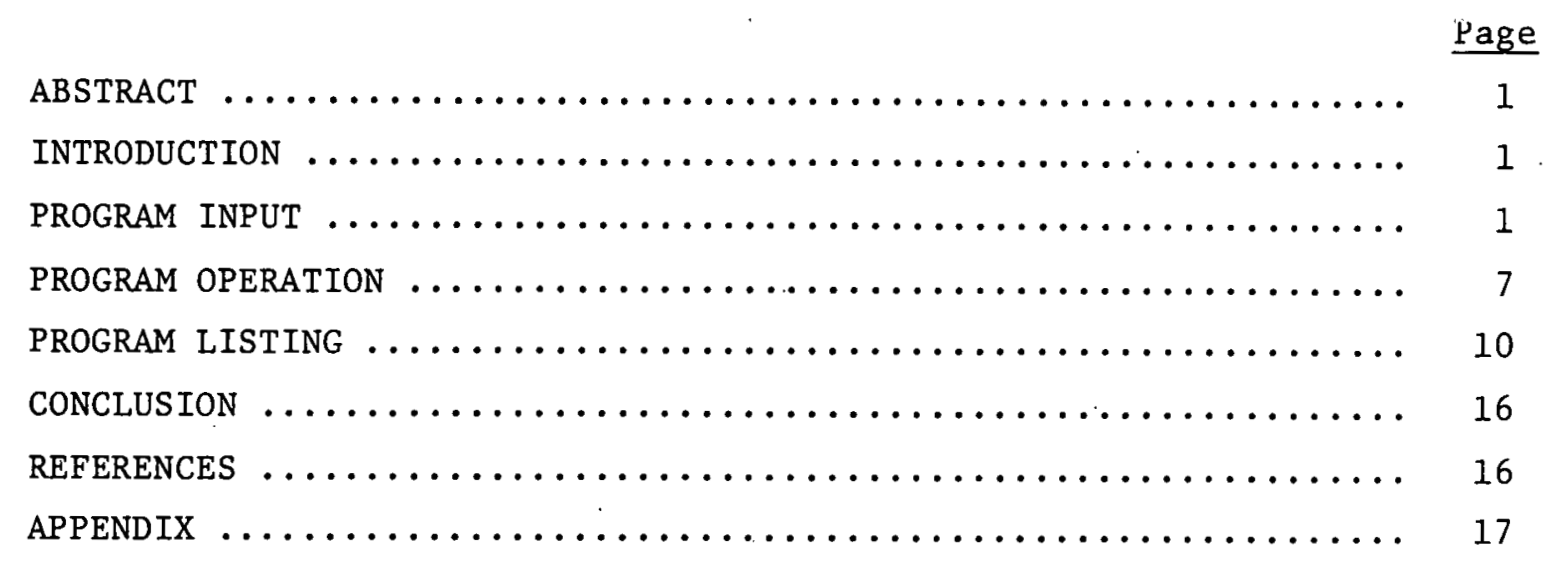




\title{
SAP3PR: A FORTRAN PROGRAM FOR CALCULATING EQUIVALENT \\ NODAL LOADS RESULTING FROM PRESSURE ON THE FACES \\ OF 8- TO 20-NODE ISOPARAMETRIC ELEMENTS
}

\author{
D. N. Fanning
}

ABSTRACT

A computer program is described for calculating the equivalent nodal loads resulting from distributed loads on a three-dimensional finite-element model. Included is a listing of the computer program, a description of the input data, and an example of the output.

\section{INTRODUCTION}

Pressure loads or distributed loads comprise at least part of the load on most structures analyzed using three-dimensional finite-element computer programs. Unfortunately, not all finite-element codes allow the user to specify pressure loads directly (e.g., NONSAP and ADINA). For codes such as these, only loads acting at the nodes are acceptable as input. Therefore, before the effects of a pressure load can be analyzed, it is necessary to convert the distributed loads into equivalent nodal loads. The computer program SAP3PR was written expressly for this purpose. SAP3PR was written for the Digital Equipment Corporation PDP-10 using the Fortran language; with minor modifications the program can be executed on the IBM 360 or 370 computer. A listing is presented in the next section, and examples of the input to and output from the program are given in the appendix.

\section{PROGRAM INPUT}

The input cards for the program are of two types: model definition cards and load case definition cards. The model definition cards define the geometry of the finite-element analytical model, while the load case cards describe the pressure loadings. The format (in parentheses), vartable names, and variable definitions are given for cach card. 


\section{Model Definition Cards}

Model Control Card $(4 I 5,4 X, L 1)$

$\begin{array}{rll}\text { Columns } & \text { Variable } & \text { Definition } \\ 1-5 & \text { NUMNP } & \text { Number of nodes } \\ 6-10 & \text { NUMEL } & \text { Number of elements } \\ 11-15 & \text { NLOAD } & \text { Number of load cases } \\ 16-20 & \text { NUMLTM } & \text { Maximum number of pressure } \\ & \text { NONSAP } & \text { Flag indicating type of format } \\ 25 & & =\text { T for NONSAP }{ }^{1} \text { or ADINA } \text { format }^{2} \\ & & \text { F for STATIC-SAP format }\end{array}$

Node Cards $(35 \mathrm{X}, 3 \mathrm{~F} 10.0)$

$\begin{array}{lll}\text { Columns } & \text { Variable } & \text { Definition } \\ 36-45 & \mathrm{XY}(1, \mathrm{I}) & \mathrm{X} \text {-coordinate of the Ith node } \\ 46-55 & \mathrm{XY}(2, \mathrm{I}) & \text { Y-coordinate of the Ith node } \\ 56-65 & \mathrm{XY}(3, \mathrm{I}) & \text { Z-coordinate of the Ith node }\end{array}$

Node cards must be input consecutively and in ascending order.

Element Cards $(/ 815 / 1215)$ or $(/ 2014)$

\begin{tabular}{|c|c|c|}
\hline \multirow[t]{11}{*}{ Columns } & Variable & Definition \\
\hline & $\operatorname{LNODE}(1, I)$ & Node 1 of element I \\
\hline & $\operatorname{LNODE}(2, I)$ & Node 2 of element I \\
\hline & $\operatorname{LNODE}(3, I)$ & Node 3 of element I \\
\hline & $\operatorname{LNODE}(4, T)$ & Norle 4 of element I \\
\hline & $\operatorname{LNODE}(5, \mathrm{I})$ & Node 5 of element I \\
\hline & $\operatorname{LNODE}(6, I)$ & Node 6 of element I \\
\hline & $\operatorname{LNODE}(7, \mathrm{I})$ & Node 7 of element I \\
\hline & $\operatorname{LNODE}(8, I)$ & Node 8 of element I \\
\hline & $\operatorname{LNODE}(9, I)$ & Node 9 of element I \\
\hline & $\operatorname{LNODE}(10, I)$ & Node 10 of element \\
\hline
\end{tabular}


Element Cards $(/ 8 I 5 / 12 I 5)$ or $(/ 2014)$ (continued)

\begin{tabular}{|c|c|c|}
\hline \multirow[t]{11}{*}{ Columns } & Variable & Definition \\
\hline & $\operatorname{LNODE}(11, I)$ & Node 11 of element I \\
\hline & $\operatorname{LNODE}(12, I)$ & Node 12 of element I \\
\hline & $\operatorname{LNODE}(13, \mathrm{I})$ & Node 13 of element I \\
\hline & $\operatorname{LNODE}(14, I)$ & Node 14 of element I \\
\hline & $\operatorname{LNODE}(15, I)$ & Node 15 of element I \\
\hline & $\operatorname{LNODE}(16, I)$ & Node 16 of element I \\
\hline & $\operatorname{LNODE}(17, I)$ & Node 17 of element I \\
\hline & $\operatorname{LNODE}(18, \mathrm{I})$ & Node 18 of element I \\
\hline & $\operatorname{LNODE}(19, I)$ & Node 19 of element I \\
\hline & $\operatorname{LNODE}(20, I)$ & Node 20 of element I \\
\hline
\end{tabular}

The first format listed for the element cards is the format used by NONSAP and ADINA (NONSAP $=T$ on the model control card); the second format is for STATIC-SAP (NONSAP $=F$ on the model control card). The element cards must be input in ascending order with no elements omitted. The sequence of nodes defining the variable node isoparametric element is shown in Fig. 1; the finite-element codes NONSAP, ADINA, and STATIC-. SAP (a modified version) use this numbering scheme for their threedimensional isoparametric element. If a nodal sequence different from Fig. 1 is needed (such as for the 20-node element of the unmodified version of STATIC-SAP), appropriate changes could easily be made in SAP3PR.

2. Load Case Definition Cards

Input NLOAD groups of load case definition cards.

Load Control Card (4I5)

\begin{tabular}{|c|c|c|}
\hline Columns & Variable & Definition \\
\hline $1-5$ & NFACE & $\begin{array}{l}\text { Number of element faces which are } \\
\text { pressurized }\end{array}$ \\
\hline $6-10$ & INT & $\begin{array}{l}\text { Order of numerical integration } \\
\text { to be used (default }=3 \text { ) }\end{array}$ \\
\hline
\end{tabular}




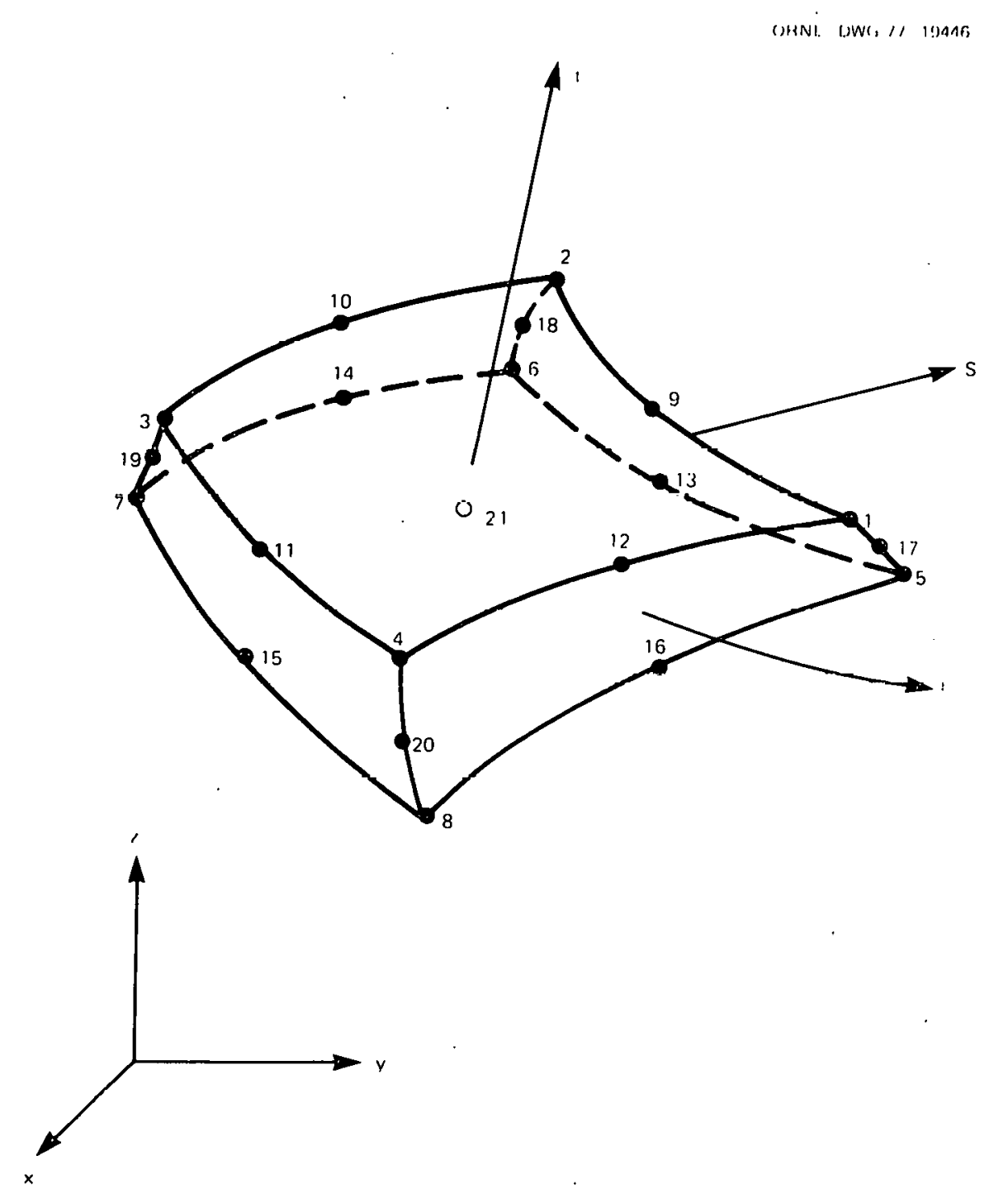

Fig. 1. Three-dimensional finite-element node numbering convention.

Load Control Card (4I5) (continued)

$\begin{array}{lll}\text { Columns } & \text { Variable } & \text { Definition } \\ 11-15 & \text { NCUR } & \text { Number of the load curve to which } \\ & \text { this load case corresponds } \\ 16-20 & \text { NUMLT } & \text { Number of pressure distributions }\end{array}$

In general, the pressure loads should be calculated using the same order of integration as will be used in the finite-element analysis. If 
the pressurized element faces are flat and rectangular and the pressure is constant or varies linearly, INT can be reduced to 2 with no loss of accuracy. NCUR is the number of the load curve in the finite-element analysis to which this load case corresponds; NCUR is not used in SAP3PR but is placed on the nodal load cards output by SAP3PR.

Pressure Cards $(8 \mathrm{~F} 10.0)$

\begin{tabular}{|c|c|c|}
\hline Columns & Variable & Definition \\
\hline $1-10$ & $\operatorname{PRESR}(1, I)$ & $\begin{array}{l}\text { Magnitude of the Ith pressure } \\
\text { distribution at face node } 1\end{array}$ \\
\hline $11-20$ & $\operatorname{PRESR}(2, I)$ & $\begin{array}{l}\text { Magnitude of the Ith pressure } \\
\text { distribution at face node } 2\end{array}$ \\
\hline $21-30$ & $\operatorname{PRESR}(3, I)$ & $\begin{array}{l}\text { Magnitude of the Ith pressure } \\
\text { distribution at face node } 3\end{array}$ \\
\hline $31-40$ & $\operatorname{PRESR}(4, I)$ & $\begin{array}{l}\text { Magnitude of the Ith pressure } \\
\text { distribution at face node } 4\end{array}$ \\
\hline $41-50$ & $\operatorname{PRESR}(5, I)$ & $\begin{array}{l}\text { Magnitude of the Ith pressure } \\
\text { distribution at face node } 5\end{array}$ \\
\hline $51-60$ & $\operatorname{PRESR}(6, I)$ & $\begin{array}{l}\text { Magnitude of the Ith pressure } \\
\text { distribution at face node } 6\end{array}$ \\
\hline $61-70$ & $\operatorname{PRESR}(7, I)$ & $\begin{array}{l}\text { Magnitude of the Ith pressure } \\
\text { distribution at face node } 7\end{array}$ \\
\hline $71-80$ & $\operatorname{PRESR}(8, I)$ & $\begin{array}{l}\text { Magnitude of the Ith pressure } \\
\text { distribution at face node } 8\end{array}$ \\
\hline
\end{tabular}

There should be NUMLT pressure cards, one for each pressure distribution. To properly specify surface pressures, it is necessary to sequence the six faces and the eight nodal points (NOF1, NOF2, ..., NOF8) on each face. The six faces of the element are defined according to Fig. 1 as follows: face $1(R=1)$, face $2(S=1)$, face $3(T=1)$, face $4(R=-1)$, face $5(S=-1)$, face $6(T=-1)$. Each face contains either $\mathrm{N} 1$ or N7, which will be used as the first of the eight face nodes. Figure 2 shows the arrangement of the face nodes. Using Fig. 2 in conjunction 


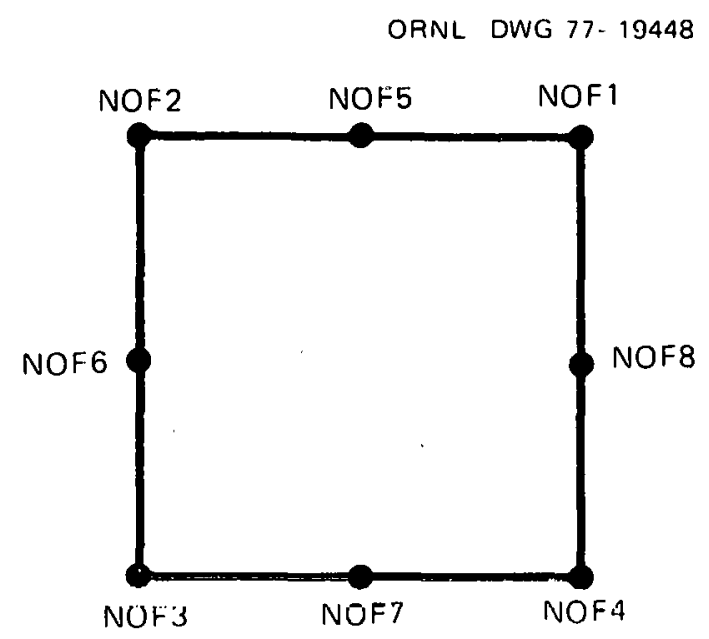
face.

Fig. 2. Node numbering convention of a three-dimensional element

with Fig. 1 results in the following nodal sequence for each face:

$\begin{array}{ccccccccc}\text { FACE } & \text { NOF1 } & \text { NOF2 } & \text { NOF3 } & \text { NOF4 } & \text { NOF5 } & \text { NOF6 } & \text { NOF7 } & \text { NOF8 } \\ 1 & \text { N1 } & \text { N4 } & \text { N8 } & \text { N5 } & \text { N12 } & \text { N20 } & \text { N16 } & \text { N17 } \\ 2 & \text { N1 } & \text { N5 } & \text { N6 } & \text { N2 } & \text { N17 } & \text { N13 } & \text { N18 } & \text { N9 } \\ 3 & \text { N1 } & \text { N2 } & \text { N3 } & \text { N4 } & \text { N9 } & \text { N10 } & \text { N11 } & \text { N12 } \\ 4 & \text { N7 } & \text { N3 } & \text { N2 } & \text { N6 } & \text { N19 } & \text { N10 } & \text { N18 } & \text { N14 } \\ 5 & \text { N7 } & \text { N8 } & \text { N4 } & \text { N3 } & \text { N15 } & \text { N20 } & \text { N11 } & \text { N19 } \\ 6 & \text { N7 } & \text { N6 } & \text { N5 } & \text { N8 } & \text { N14 } & \text { N13 } & \text { N16 } & \text { N15 }\end{array}$

Face Card (3I5)

$\begin{array}{lll}\text { Columns } & \text { Variable } & \begin{array}{l}\text { Definition } \\ 1-5\end{array} \\ 6-10 & \text { NUMF } & \begin{array}{l}\text { Number of the pressurized element } \\ \text { Number of the face which is } \\ \text { pressurized }\end{array} \\ 11-15 & \text { LODTYP } & \begin{array}{l}\text { Number of the pressure distribu- } \\ \text { tion which acts on this face } \\ \end{array} \\ & \text { (default }=1 \text { ) }\end{array}$

There should be NFACE face cards. 
PROGRAM OPERATION

Equivalent nodal forces due to distributed loads are given by the following equation (Ref. 4):

$$
\{F\}=-\int[N]^{T}\{p\} d V
$$

with the integration being over the volume of the loaded element. The matrix [N] is composed of the shape functions as follows:

$$
\left.\begin{array}{rl}
\mathrm{n}_{1,3 i-2} & =h_{i} \\
\mathrm{n}_{1,3 i-1} & =0 \\
\mathrm{n}_{1,3 i} & =0 \\
\mathrm{n}_{2,3 i-2} & =0 \\
\mathrm{n}_{2,3 i-1} & =h_{i} \\
\mathrm{n}_{2,3 i} & =0 \\
\mathrm{n}_{3,3 i-2} & =0 \\
\mathrm{n}_{3,3 i-1} & =0 \\
\mathrm{n}_{3,3 i} & =h_{i}
\end{array}\right\} \quad(i=1,2, \ldots, m)
$$

where $h_{i}$ is the shape function for node $i, n_{j, k}$ is the term in the $j \underline{t h}$ row and $k$ th column of $[N]$, and $m$ is the number of nodes the element has. The terms of the vector $\{\mathrm{p}\}$ are the components of the distributed load in the global coordinate directions. Since $\{p\}$ is zero except on the face which is pressurized, it is only necessary to integrate over the surface of the pressurized face, not the volume of the element. Numerical integration is used after the face has been mapped into the local two-dimensional $u, v$-space as shown in Fig. 3. Assuming that one of the global coordinates $(x, y$, or $z)$ is a function of the other two, the 


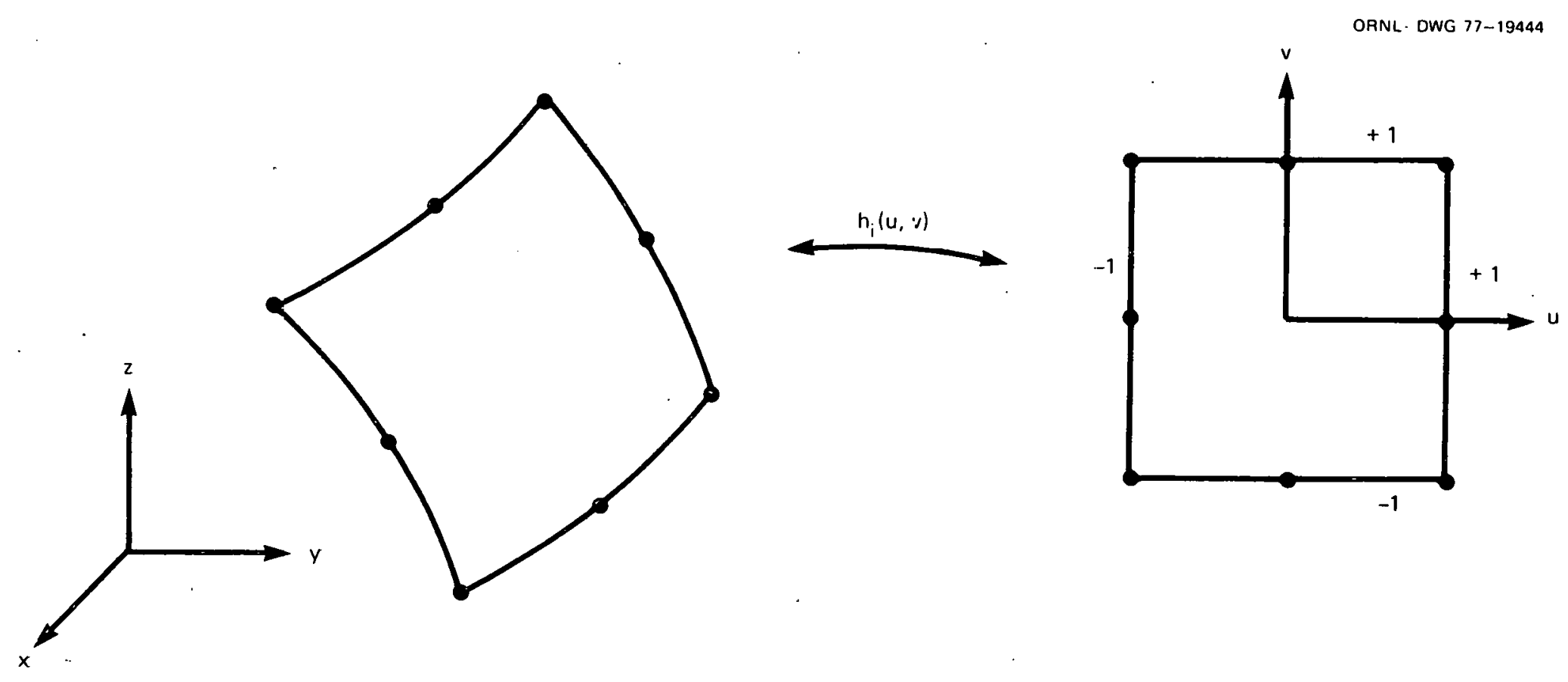

Fig. 3. Mapping of a pressurized face into a local two-dinens,ional space. 
following expression can be obtained:

$$
\{F\}=\int_{-1}^{1} \int_{-1}^{1}[\overline{\bar{N}}]^{T}\{\bar{p}\} d u d v
$$

where

$$
\{\bar{p}\}=\left\{\begin{array}{c}
\frac{\partial z}{\partial u} \frac{\partial y}{\partial v}-\frac{\partial y}{\partial u} \frac{\partial z}{\partial v} \\
\frac{\partial x}{\partial u} \frac{\partial z}{\partial v}-\frac{\partial z}{\partial u} \frac{\partial x}{\partial v} \\
\frac{\partial y}{\partial u} \frac{\partial x}{\partial v}-\frac{\partial x}{\partial u} \frac{\partial y}{\partial v}
\end{array}\right\} P_{n},
$$

and $p_{n}$ is the magnitude of the pressure, a function of $u$ and $v$

$$
\left[p_{n}=\sum_{i=1}^{1} p_{i} h_{i}(u, v)\right] \text {. }
$$

The matrix $[\overline{\mathrm{N}}]$ is composed of the shape functions for the nodes on the pressurized face.

The program expects the input data to be in a disk file named FOR21.DAT. After reading the model control card, the program sets up the pointers necessary for the vector storage and checks to see if sufficient space is avallable in blank common. The output, which is compatible with ADINA, NONSAP, or STATIC-SAP, depending upon the value of the variable NONSAP on card 1 , is written into a disk file named FOR22. DAT. 
PROGRAM IISTING

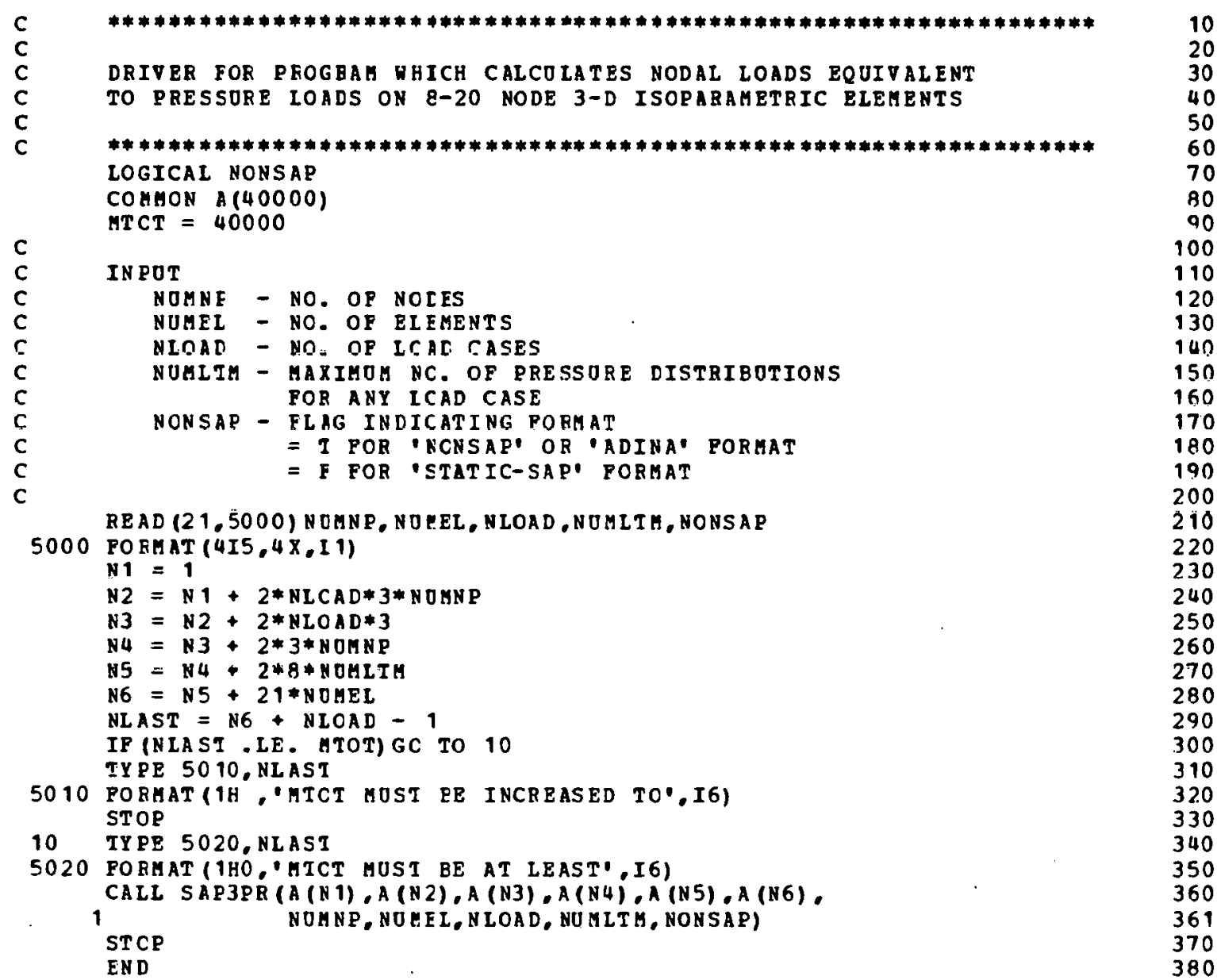

SOBROUTINE SAP $3 F R$ (F, FSOM, XY,PRESR, LNODE, NC, SAP3P 10 1 NOMNE, NOREL, NLOAD, NOMLTM, NONSAP) SAE3P 11

C $\quad * * * * * * * * * * * * * * * * * * * * * * * * * * * * * * * * * * * * * * * * * * * * * * * * * * * * * * * * * * * * * * * * * * \operatorname{SAP} 3 \mathrm{P}$ 2.O

PROGBAM TO CALCOLATE NODAL LOADS EQOIVALENT TO PRESSORE LOADS SAP3P 40 ON 8-20 NODE 3-D ISOPARAMETRIC ELEMENTS

SAP3P 60

******************************************************************SAP3P 70

SAF 3P 80

$\begin{array}{ll}\text { *** CEFINITION OF VARIAELES *** } & \text { SAP3P } 90 \\ & \text { SAP3 } 100\end{array}$

$P(I, J, K)$ - RESULTING LOAD IN 'J'TH DIRECTION ON NODE 'K' PCR SAP3 110 T.CAD CASE 'I'
SAP3 120

IDGEN - FLAG POR DEGENERATE EDGES OP AN ELEHENT

LM - ELEMENT MHICH IS LOADED $\quad$ SAP3 140

INCDE (I,J) - I'TH NOLE OF THE 'J'TH ELEHENT

LODTYP - NOHBER CF PRESSORE DISTRIBOTION ON THE FACE

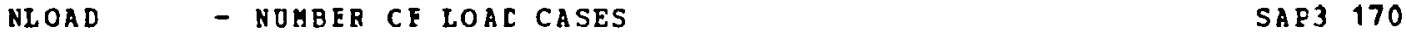

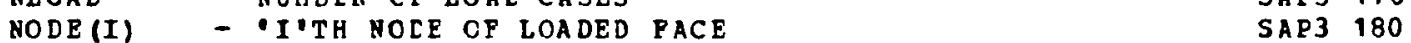

NONSAP - FLAG INC]CATING PORMAT $\quad$ SAP3 190

$=T$ POR 'NONSAP' OR 'ADINA' FORKAT SAP3 200

$=F$ POR 'STATIC-SAP' PORMAT SAP3 210 


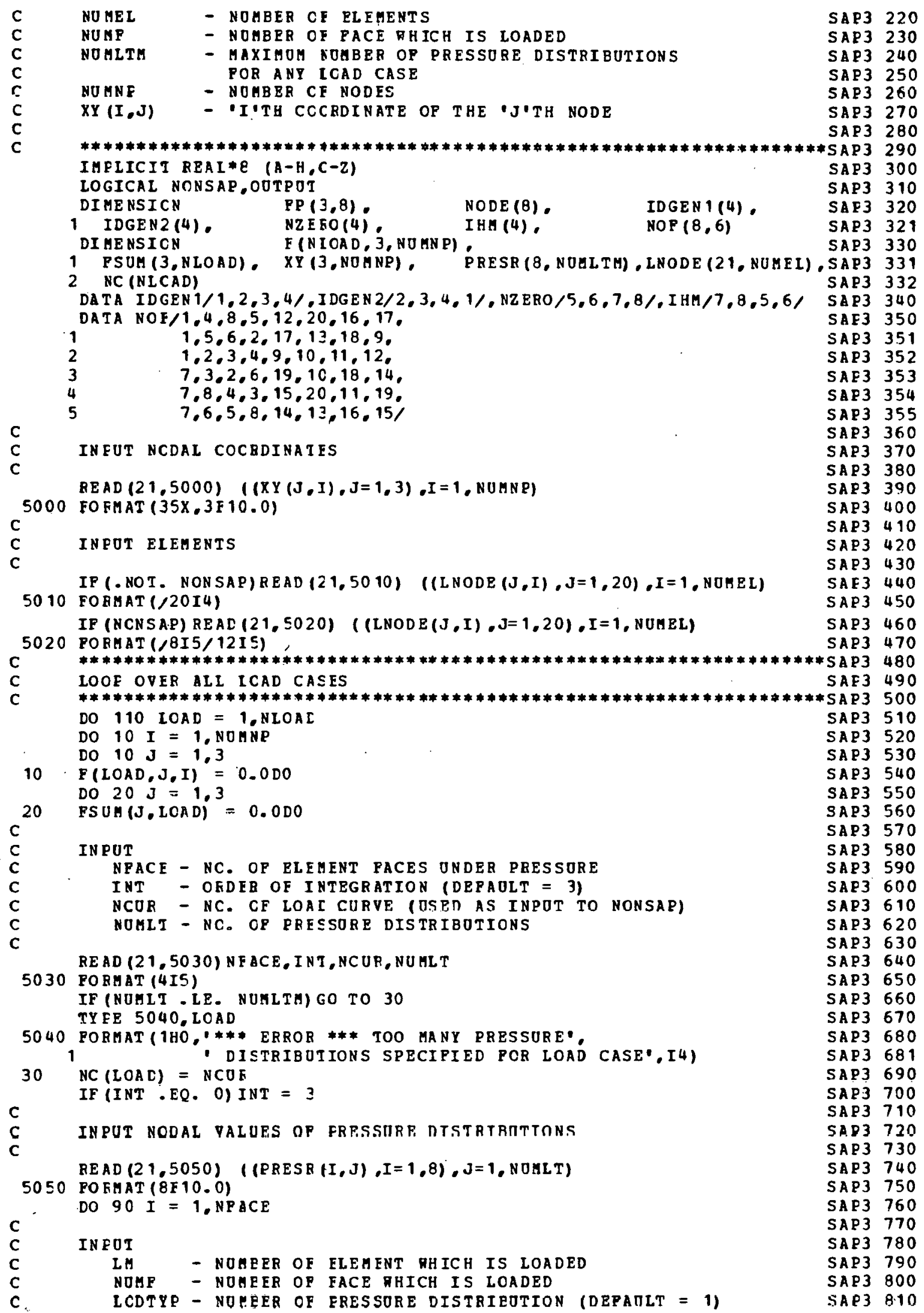


C

READ $(21,5060)$ LE, NOEF, LODTYP

5060 FOEMAT (3IS)

IF (LODTYE OEC. O) LODTYP = 1

IP (IM. IE.NOMEL A AND. NOME . LE. 6 - AND.

1 LODTYP.LE. NOHLT) GC TO 40

TY PE 5070, LM, NOEF, LOCIYP

5070 FORHAT (1H0,*** ERROF ***?, 3I5)

STCP

40 DO $50 \mathrm{~J}=1.8$

$50 \operatorname{NODE}(J)=\operatorname{INCDE}(\operatorname{NOF}(J, N O H F), \operatorname{LH})$

C CHECK FOR DEGENERATE FDGES

C

$I 2=0$

IDGEN $=0$

DO $6011-1.4$

IP ( (NODE (IHA (I 1)) , EC. O) .OR.

1 (NODE(IDGEN1(I 1)) . NE. NODE(IDGEN2(I 1)))) GO TO 60 NOCE (NZERO (I 1)) $=0$

$I 2=I 2+1$

IDGEN $=$ II

60 CONTINOE

IP (I2 - LT. 2) GC TO $7 \mathrm{C}$

TY PE $5080, N O M P, I M$, NOCE

5080 FORMAT (140.*** ERROR *\#* FACE', I2, OF ELEHENT'. I4.

1

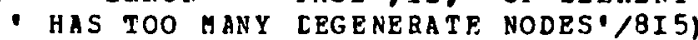

STOP

C CAICOLATE NODAI LOADS CN THIS FACE

70 CALL FOECE (FP, XY, NODE,INT, FRESR (1, LCDTYP), IDGEN)

c

C ADD CONTEIBOIICN OF IPIS FACE

C

DO $80 \mathrm{~J}=1.8$

NODEI $=$ NODE (J)

IF (NCDEI . EQ. 0) GO TO 80

$F(I O A D, 1$, NODEI $)=P(L C A D, 1$, NODEI $)+P P(1, J)$

$P(L O A D, 2, N O D E I)=P(L C A D, 2, N O D E I)+P P(2, J)$

$F(L C A D, 3$, NODEI $)=P(L C A D, 3$, NODEI $)+P P(3, J)$

80 CONTINOE

90 CONTINUE

IF (. NOT. NONSAF)GO TC 110

SAP 3820

SAP 3830

SAP3 840

SAP3 850

SAP 3860

SAP 3861

SAP 3870

SAP 3880

SAP 3890

SAP3 900

SAP 3910

SAP 3920

SAP3 930

SAP 3940

SAP3 950

SAP 3960

SAP3 970

SAP 3980

SAP 3981

SAP 3990

SAP 1000

SAE 1010

SAP 1020

SAP 1030

SAP 1040

SAP 1050

SAP 1051

SAP 1060

SAP 1070

SAP 1080

SAP 1090

SAP 1100

SAP 1110

SAP 1120

SAP 1130

SAP 1140

SAP 1150

SAP 1160

SAP 1170

SAF 1180

SAP 1190

SAP 1200

SAP 1210

SAP 1220

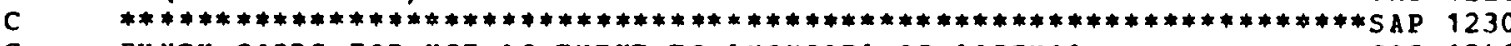

C PUNCH CARDS FOE USF AS INPUT TC 'NCNSAP' OR 'ADINA'

SAP 1240

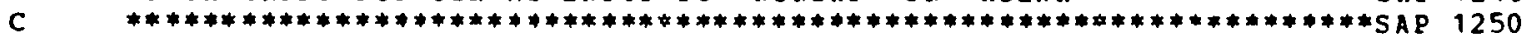

$I 2=0$

DO 100 II $=1$, NOHN

DO $100 \mathrm{~J}=1.3$

FSUY $(J, L O A D)=$ FSUM $(J, L O A D)+P(L O A D, J, I 1)$

IF (DABS (F (LOAD,J,I1)) .LE. 5.0D-2) GO TO 100

$I 2=I 2+1$

WRITE $(22,5090)$ I 1,J,NC (IOAD),F(LOAD,J,I1)

5090 FOFHAT (3I5, F 10.1)

100 CONTINOE

TY PE $5100, I 2, N C(L O A D),(P S O M(J, L O A D), J=1,3)$

5100 FOEHAT (1HO,I5, LOAD CARDS FOR LOAD CORVE' I3/

110 CONTINUE $1 \mathrm{H}$, SUMX $=0$, F14.1. SOMY $=1, \mathrm{P} 14.1$.

SAP 1260

SAP 1270

SAP 1280

SAP 1290

SAP 1300

SAP 1310

SAP 132.0

SAP 1330

SAP 1340

SAP 1350

SAF 1360

IF (NCNSAP) RETUSN

SUMZ $=\bullet$,F14.1) SAF 1361

SAP 1370

SAP 1380

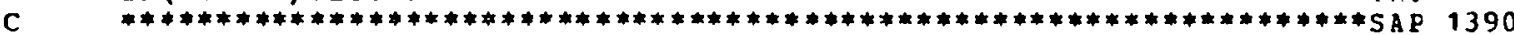

C PUNCH CARDS POE OSE AS INPOT TO STATIC-SAP' SAP 1400

C $\quad * * * * * * * * * * * * * * * * * * * * * * * * * * * * * * * * * * * * * * * * * * * * * * * * * * * * * * * * * * * * * * * * * *$ SAP 1410

$12=0$

DO $130 I=1$, NOKNP

DO 130 LOAD $=1$, NLOAC

SAP 1420

SAP 1430

SAP 1440

DO $120 \mathrm{~J}=1.3$

SAP 1450 


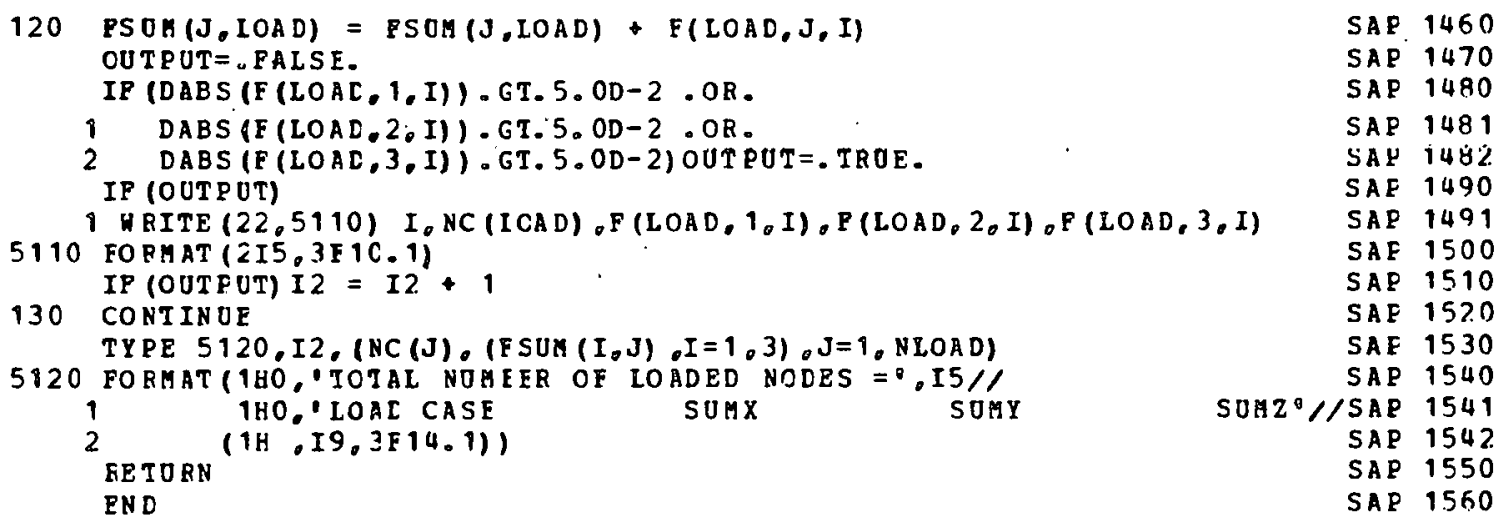

SUBROUTINE FORCE (P,XY, DODE, INT,PRES, IDGEN) PORCE 10

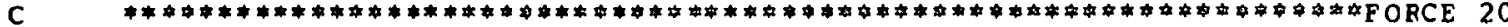

C SURRCOTINE TO CALCOLATE NODAL LOADS TUE TO PRESSURE ON THE

C SURPACE OF A 3-D ISOFARAMETRIC ELEAENT OP THE 'SERENDIPITY" FAMILY

FORCE 40

FORCE 50

PORCE 60

FOKCE 70

C

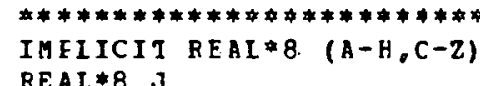
PORC 340 FORC 350 $F \cap B C \quad 360$ FORC 370 


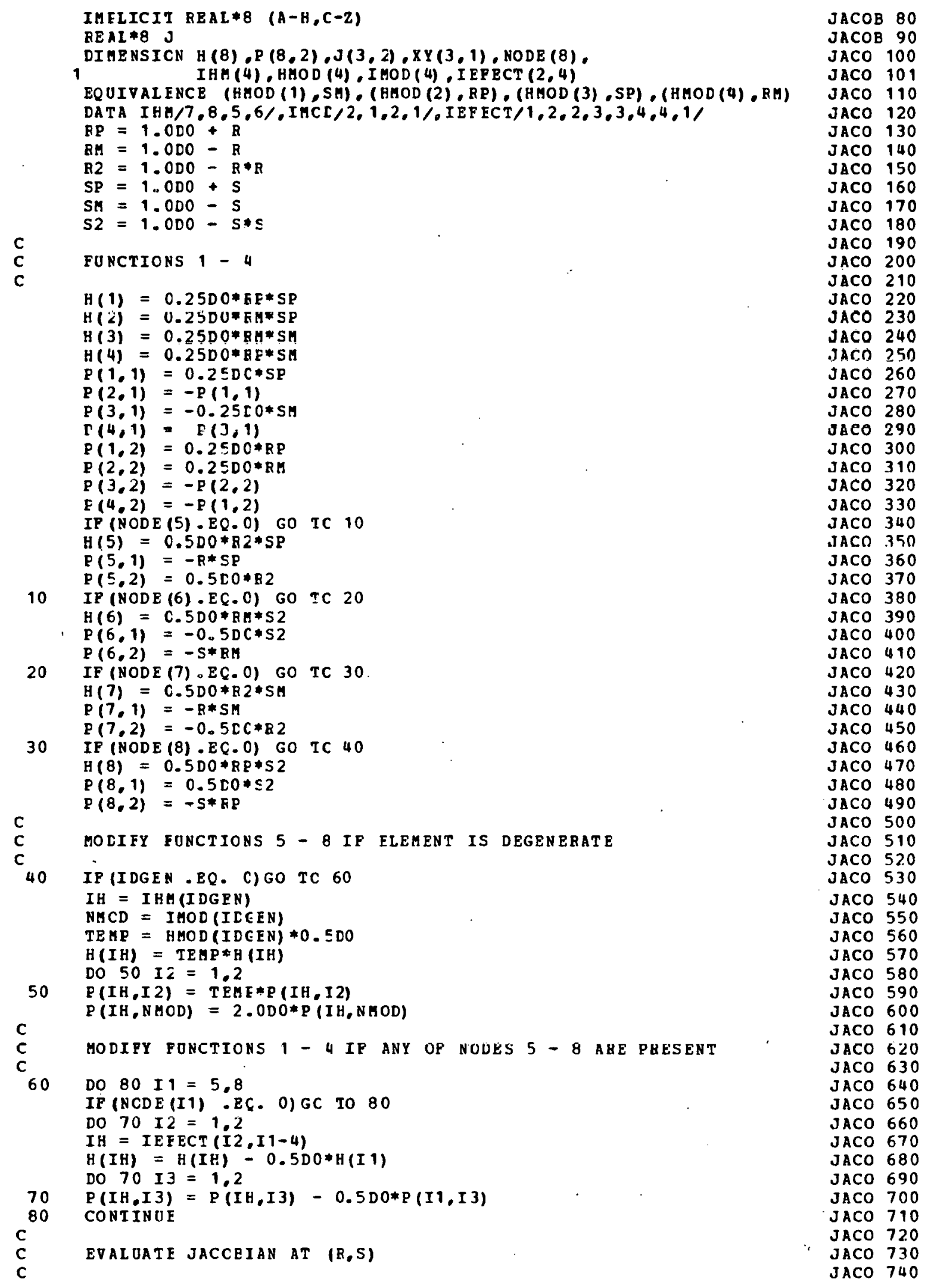




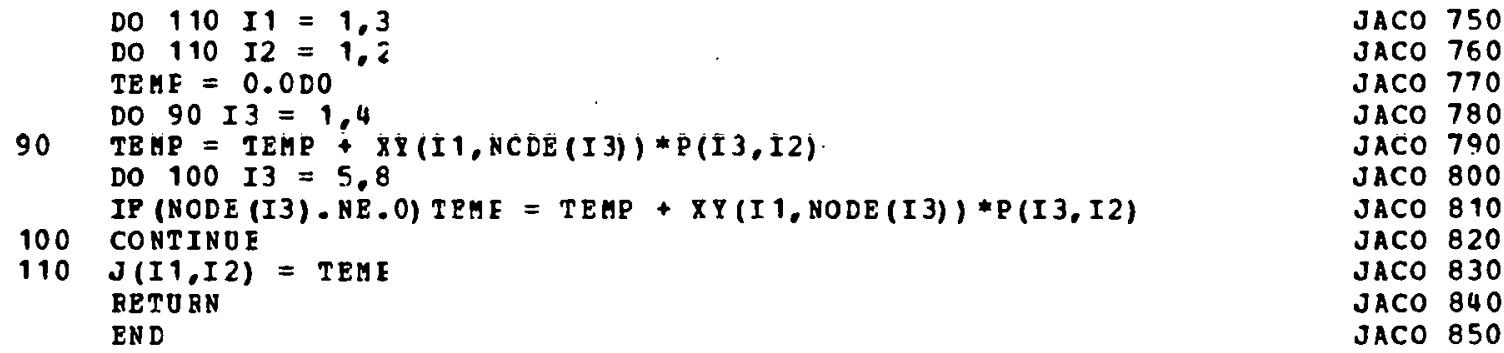

SUBROUTINE GAOSS (C,, INT, I F)

GAUSS 10

GAOSS PCINT ANL HEIGHTING VALOE POR INTEGRATION ORDER 'INT' AT (t)

GAUSS 30 POINT NOHEER 'IF'

40

GAOSS 50 GAUSS 60

IHELICII REAL $* 8 \quad(\mathrm{~A}-\mathrm{H}, \mathrm{C}-\mathrm{Z})$

CIUENSION WT $(S, 9)$, DATA TT/ 2.000 .

$A B(9,9)$ GAOSS 80

$.5555 \subseteq 55555555560$

GAOSS 90 $6 * 0.000$ $7 * 0.000$ GAUS 100 88888888888888900,55555555555555600 GAOS 101 .652145154862546CO,GADS 104 $.347854 \varepsilon 4513745400$. 5*0.0D0. GAOS 105 $.236926 \varepsilon 85056189 \mathrm{DO}, .478628670499366 \mathrm{DO}, .568888888888889 \mathrm{DO}$, GAOS 106 .47862867049936600 . . 236926885056189DO. 4*0.0DO,GAOS 107 $.171324492379170 \mathrm{DO}, .360761573048139 \mathrm{DO}, .467913934572691 \mathrm{DO}$, GAOS 108 $.467913934572691 \mathrm{DO}, .360761573048139 \mathrm{DO}$. . 1713244 S2379170E0,GAOS 109 $3 * 0.000$ GAOS 109

$.129484966168870 \mathrm{DO} . .279705391489277 \mathrm{DO}, .381830050505119 \mathrm{CO}, \mathrm{GAOS} 109$ $.41795918367346900 .381830050505119 \mathrm{DO} . .279705391489277 \mathrm{DO}$, GAOS 109

$.129424 C 6616827000$. 2*0.000. GAUS 109

$.101228536290376 \mathrm{DO}, .222381034453374 \mathrm{DO}$. . $313706645877887 \mathrm{DO}, \mathrm{GAUS} 109$ $.362683783378362 \mathrm{DO}: .3626837 \varepsilon 3378362 \mathrm{DO} .313706645877887 \mathrm{DO}$. GA OS 109 $.222381 C 3445337400, .101228536290376 \mathrm{DO}$, 0.0LO.GAUS 109 $.08127438836157400,-18064816069485700,-26061069640293500$.GAUS 109 $.312347 C 77 C 400 C 3 D 0$. .330239355001260D0,.312347077040003[0,GAUS 109 $.260610696402935 \mathrm{DO}$. $180648160694857 \mathrm{DO}, .081274388361574 \mathrm{CO} / \mathrm{GAOS} 109$

DATA AE/ 9*C.ODO -.577350269189626D0..577350269189626DO, 7*0.0DO,GAOS 111

$-.774596669241483 D 0, \quad 0.0 D 0, .774596669241483 D 0$, GAOS 112 $6 \div 0.000$.

$-861136311594 \mathrm{C} 53 \mathrm{DO}=-.339981043584856 \mathrm{DO}, \quad 339981043584856 \mathrm{DC}$ GAOS 114

$.861136311594 C 53 \mathrm{DO}$. $5 * 0.000$

$-.906179845938664 \mathrm{DO}-.538469310105683 \mathrm{DO}$.

$.538469310105683 D 0.906179845938664 \mathrm{DO}$. GAUS 115

作

.2386191860831 1S7D0..661209386466265D0. .932469514203152D0,GAUS 119 $3 * 0.000$. GAOS 119

$-.949107912342759 D 0,-.7415311 E 5599394 D 0,-.405845151377397 D 0$, GAOS 119

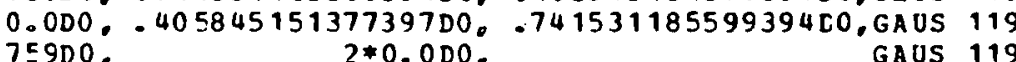

$-.960289856497536 D 0,-.79656647741362700,-.52553240991632900$, GAUS 119

$-.183434642495650 D 0.0183434642495650$ DO, .525532409916329 CO,GAOS 119

$.796666477413627 D 0, .960289856497536 \mathrm{DO}$. $0.0 \mathrm{DO}$,GAUS 119

$-.968160239507626 \mathrm{DO},-.836031107326636 \mathrm{DO},-.61337143270 \mathrm{C} 590 \mathrm{DO}, \mathrm{GAUS} 119$

-.3242534234C3EC9DO. $0.000 .0324253423403809 D C, G A O S 119$

.6133714327005 SODO. .836031107326636DO. .968160239507626 CO/GAOS 119

$C=A B(I P, I N T)$

$N=H T$ (IP, INT)

RET TOQ BN

EN D
GAUS 120

GADS 130

GAOS 140

GAUS 150

GAOS 160 


\section{CONCLUSION}

SAP3PR provides an easy way of calculating equivalent nodal loads resulting from distributed pressure loadings. The code can be easily modified to calculate nodal loads for elements with a nodal ordering which differs from that used by ADINA, NONSAP, or STATIC-SAP.

\section{REFERENCES}

1. Klaus-Jürgen Bathe, E. L. Wilson, and R. H. Iding, NONSAP: A Structural Analysis Program for Static and Dynamic Response of Nonlinear. Systems, Report UC SESM 74-3, University of California, Berkeley (February 1974).

2. Klaus-Jürgen Bathe, ADINA: A Finite Element Progrom for Automatic Dynomic Incremental Nonlinear Analysis, Report No. 82448-1, Massachusetts Institute of Technology (1975).

3. Finite Element Analysis of Mine Structures, Final Report to Denver Mining Research Center, U.S. Department of the Interior, Bureau of Mines, Contract H0110231 (September 1972).

4. '0. C. Zienkiewicz, The Finite Element Method in Engineering Science, p. 22, McGraw-Hill, London, 1971. 
APPENDIX

This appendix contains an example of the input necessary to run SAP3PR and the resulting output. The finite-element model used for this example consists of four 20-node elements as shown in Fig. A.1. Equivalent nodal loads are calculated for two load cases: one for a uniform pressure of 1000 in the negative $x$-direction and the other for a pressure in the negative $y$-direction which varies linearly with respect to the z-direction (Fig. A.2).

The input is shown first followed by the output to the teletype and disk file FOR22.DAT. [Note that the NONSAP $=\mathrm{T}$ format option is being used.] The input for load case 1 requires only one pressure card since the pressure on each element face is the same constant 1000. Load case 2 needs four pressure cards because the pressure distribution on all four elements differ. The summation of forces given by the teletype output is useful as a check on the input data. The load cards are output on unit 22 . 


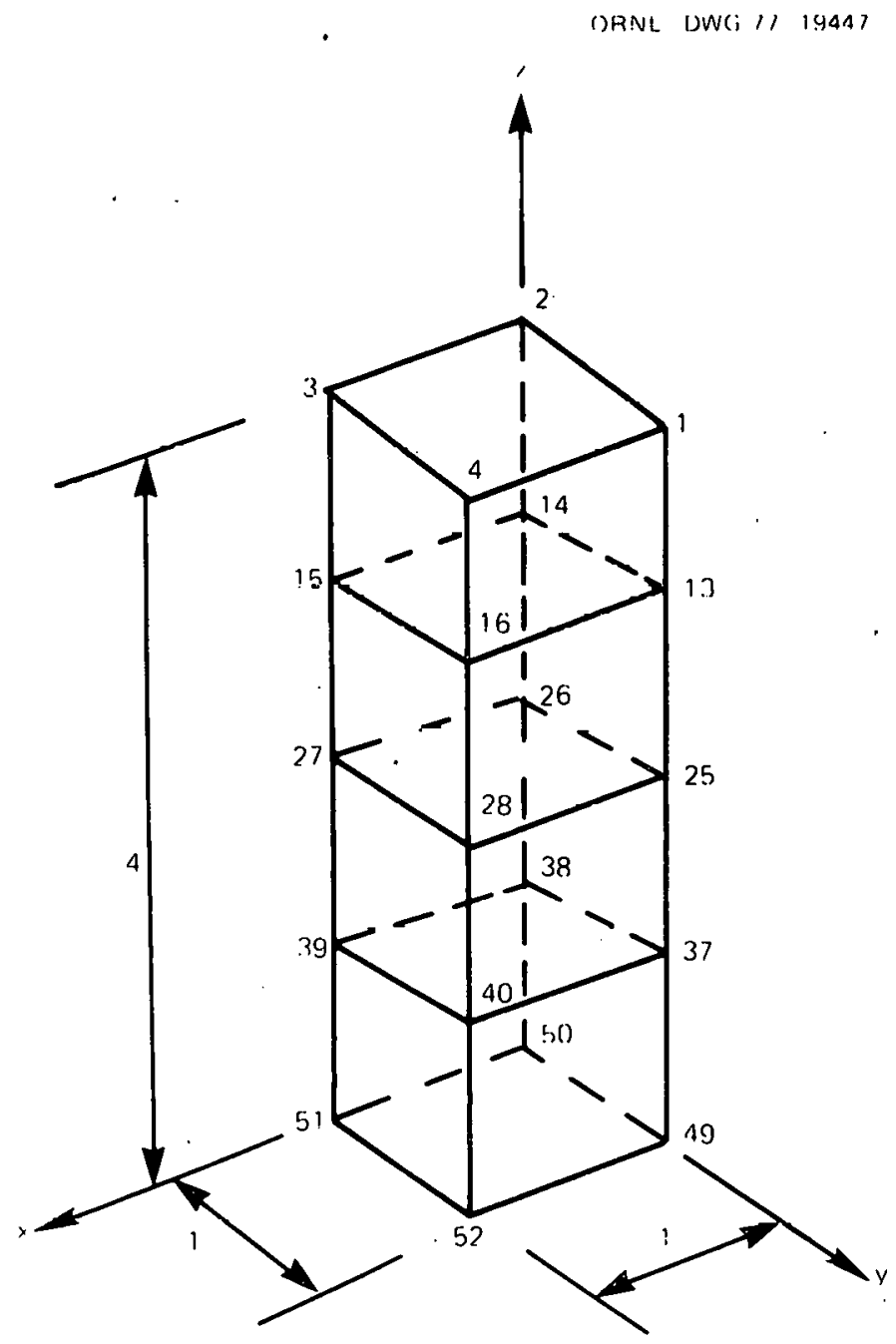

Fig. A.1. Finite-element model of example structure.
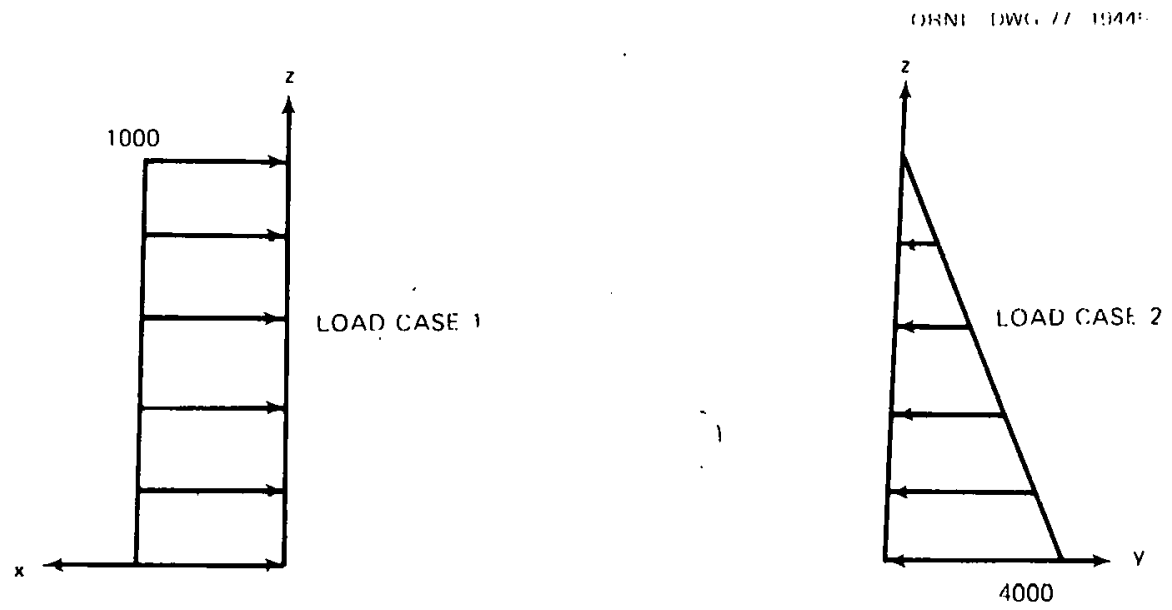

Fig. A.2. Pressure loadings on example structure. 
EXAMPLE OP INPOT

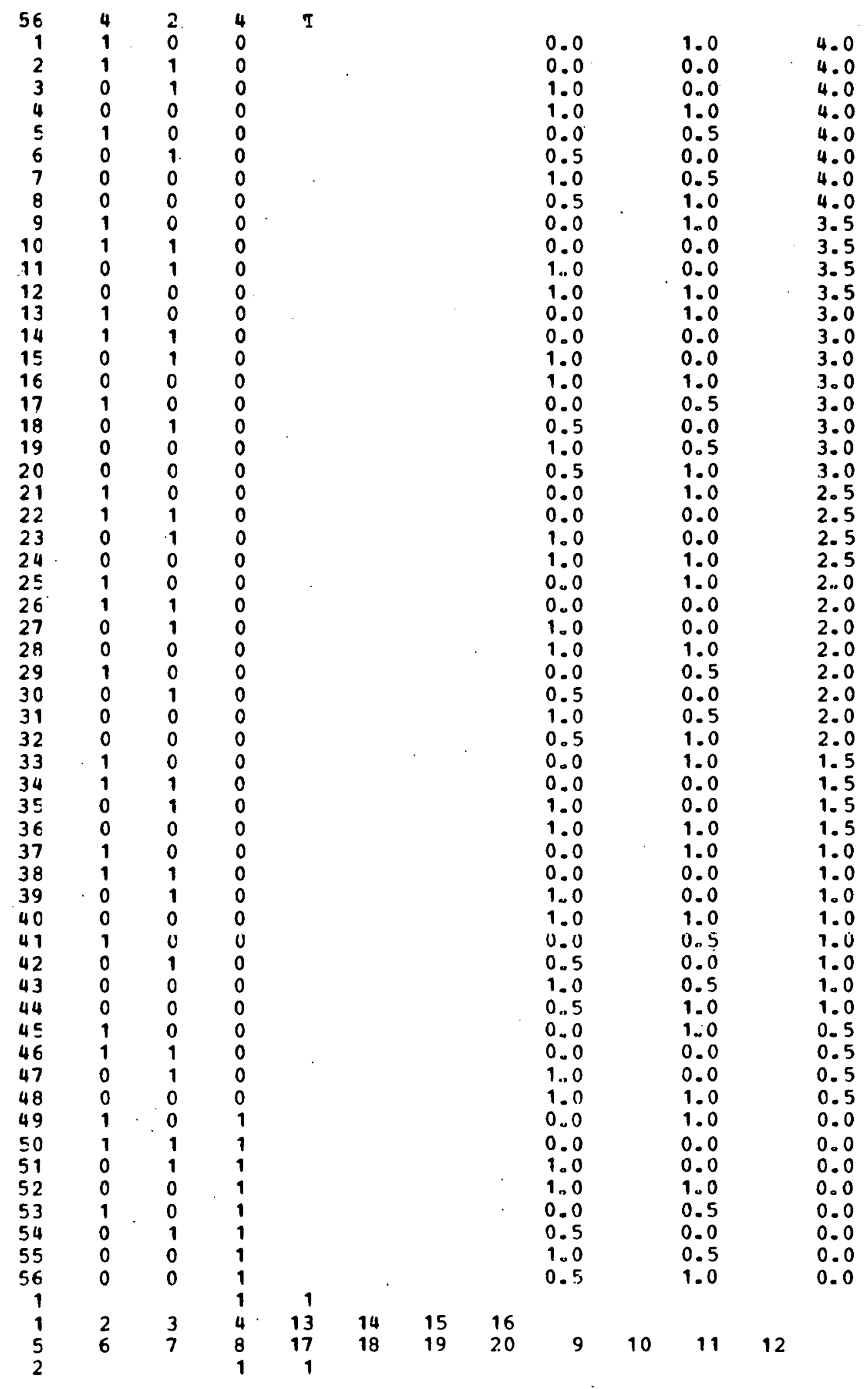




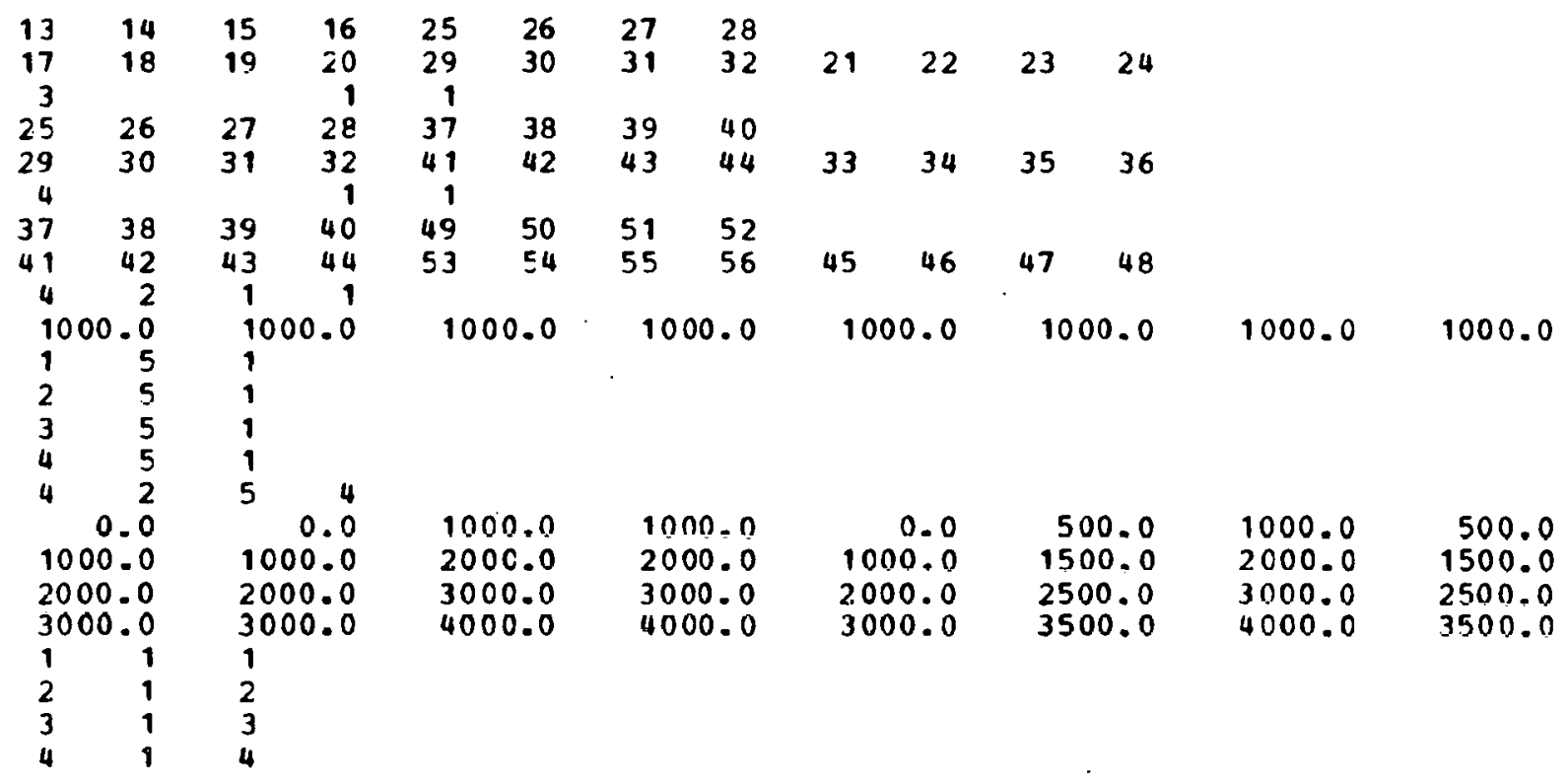


EXAMPLE OF TELETIPE OUTPUT

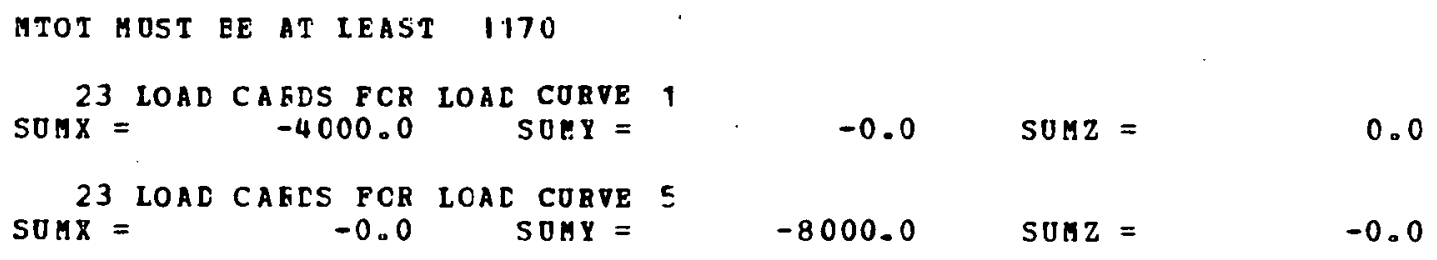


22

EXAMPIE OP UNIT 22 ODTPOT

$\begin{array}{rrrr}3 & 1 & 1 & 83.3 \\ 4 & 1 & 1 & 83.3 \\ 7 & 1 & 1 & -333.3 \\ 11 & 1 & 1 & -333.3 \\ 12 & 1 & 1 & -333.3 \\ 15 & 1 & 1 & 166.7 \\ 16 & 1 & 1 & 166.7 \\ 19 & 1 & 1 & -666.7 \\ 23 & 1 & 1 & -333.3 \\ 24 & 1 & 1 & -333.3 \\ 27 & 1 & 1 & 166.7 \\ 20 & 1 & 1 & 166.7 \\ 31 & 1 & 1 & -666.7 \\ 35 & 1 & 1 & -333.3 \\ 36 & 1 & 1 & -333.3 \\ 39 & 1 & 1 & 166.7 \\ 40 & 1 & 1 & 166.7 \\ 43 & 1 & 1 & -666.7 \\ 47 & 1 & 1 & -233.3 \\ 48 & 1 & 1 & -333.3 \\ 51 & 1 & 1 & 83.3 \\ 52 & 1 & 1 & 83.3 \\ 55 & 1 & 1 & -333.3 \\ 1 & 2 & 5 & 55.6 \\ 4 & 2 & 5 & 55.6 \\ 8 & 2 & 5 & -111.1 \\ 9 & 2 & 5 & -166.7 \\ 12 & 2 & 5 & -166.7 \\ 13 & 2 & 5 & 166.7 \\ 16 & 2 & 5 & 166.7 \\ 20 & 2 & 5 & -666.7 \\ 21 & 2 & 5 & -500.0 \\ 24 & 2 & 5 & -500.0 \\ 25 & 2 & 5 & 333.3 \\ 28 & 2 & 5 & 333.3 \\ 32 & 2 & 5 & -1333.3 \\ 33 & 2 & 5 & -833.3 \\ 36 & 2 & 5 & -833.3 \\ 37 & 2 & 5 & 500.0 \\ 40 & 2 & 5 & 500.0 \\ 44 & 2 & 5 & -2000.0 \\ 45 & 2 & 5 & -1166.7 \\ 48 & 2 & 5.7 & -1166.7 \\ 49 & 2 & 5 & 277.8 \\ 52 & 2 & 5 & 277.8 \\ 56 & 2 & 5 & -1222.2 \\ & & & \\ 15 & \end{array}$


ORNL/TM-6091

Dist. Category UC-77

\section{Internal Distribution}

$\begin{aligned} & \text { 1. } \text { S. J. Ball } \\ & \text { 2. } \text { D. E. Bartine } \\ & \text { 3-6. } \text { J. P. Callahan } \\ & \text { 7. } \text { D. A. Canonico } \\ & \text { 8. } \text { J. A. Clinard } \\ & \text { 9. } \text { J. A. Conlin } \\ & \text { 10. } \text { W. E. Cooper } \\ & \text { 11. } \text { J. M. Corum } \\ & \text { 12. } \text { J. R. DiStefano } \\ & \text { 13. } \text { W. G. Dodge } \\ & \text { 14. J. R. Dougan } \\ & \text { 15. W. P. Eatherly } \\ & \text { 6-19. D. N. Fanning } \\ & \text { 20. Uri Gat } \\ & \text { 21. D. W. Goodpasture } \\ & \text { 22. } \text { W. L. Greenstreet } \\ & \text { 23. R. C. Gwaltney } \\ & \text { 24. J. F. Harvey } \\ & \text { 25. F. J. Homan } \\ & \text { 26. P. R. Kasten } \\ & \text { 27. M. Levenson } \\ & \text { 28. A. L. Lotts } \\ & \text { 29. R. E. MacPherson } \\ & \text { 30. A. P. Malinauskas } \\ & \text { 31. B. F. Maskiwitz }\end{aligned}$
32. W. J. McAfee
33. J. G. Merkle
34. F. R. Mynatt
35. R. K. Nanstad
36. D. J. Naus
37. K. J. Notz
38. C. B. Oland
39. H. Postma
40. G. C. Robinson
41. J. P. Sanders
42. M. R. Sheldon
43. G. M. Slaughter
44. G. C. Smith
45. J. E. Smith
46. M. Tobias
47. H. E. Trammell
48. D. B. Trauger
49. J. R. Weir, Jr.
50. G. D. Whitman
51. R. P. Wichner
52. ORNL Patent Office
53-54. Central Research Library
55. Document Reference Section
56-58. Laboratory Records Department
59. Laboratory Records, ORNL-RC

\section{External Distribution}

60-61. Director, Division of Nuclear Research and Applications, DOE, Washington, D.C. 20545

62. Director, Reactor Division, DOE, ORO

63. Research and Technical Support Division, DOE, ORO

64-240. For distribution as shown in TID-4500 under category UC-77, GasCooled Reactor Technology 